ARTIKKELI

\title{
KAUPANTEON PERINTEITÄ LAPPEENRANNAN KAUPPATORILLA
}

\author{
Sari Tuuva-Hongisto
}

appeenrannan kauppatori on

- - nimenomaan kesäisin - - mieleenpainuva. Se ei kelpaa esimerkiksi rakennelmien tai järjestelyjen suhteen, siihen se on liian tavanomainen. Sen sijaan myyjät ja asiakkaat ovat sekoitus iloista karjalaisuutta, vilkkautta, kansainvälisyyttä. Lappeenrannan tori on paikka, josta löytyy riittävästi myös maakunnallista ilmettä, tuotteita ja inmisiä. Se on myös kulttuurien kohtaamispaikka, josta saa maailman ainoat Karjalan fast food-tuotteet eli Atomin ja Vedyn. (Sademies 1990.)

Lappeenrannan kauppatorilla on omia paikallisia erikoisuuksiaan sekä pitkä historia. Lappeenranta on vanha keskiaikainen kauppapaikka, jossa pidetyt tervamarkkinat olivat maan suurimpia. Kauppasuhteet olivat vilkkaat Viipurin ja Pietarin suuntaan. Nykyisen torin muistettu ja muisteltu kukoistus syntyi sotien jälkeen, kun kauppa Viipuriin loppui ja torimatkat suuntautuivat entistä enemmän Lappeenrantaan. Monien kauppiaiden juuret ulottuvat sukupolvien taakse. Esimerkiksi perunakauppiailla on puisia mitta-astioita eli kappoja 1800-luvulta ja muistoja useiden sukupolvien kaupankäynnistä. Kaupanteon juuret ulottuvat Viipurin torille, joka vilkkaampana torina veti väkeä kauempaakin Etelä-Karjalan alueelta. Torin kauppiaissa on myös monia, jotka ovat aloittaneet kaupankäyntinsä jo Lappeenrannan satamatorilla, jossa kauppatori sijaitsi vuoteen 1956 asti. Jo 1800-luvun lopulla eri paikkakunnat olivat erikoistuneet tiettyihin tuotteisiin (Lindh 1885). Samat tuotteet näkyvät osittain yhä torikuvassa: Lemin perunat, Nuijamaan mansikat, lappeelaiset Viipurin rinkelit sekä 1960-luvulta lähtien kahvikojuissa myydyt täytetyt lihapiirakat eli "vedyt ja atomit" ovat edelleen osa torin omaleimaisia piirteitä.

Artikkelini pohjautuu tutkimukseeni Lappeenrannan kauppatorista (Tuuva-Hongisto 2017). Käsittelen artikkelissani päivittäin tehtävää paikallista torikauppaa, erotuksena markkina- tai tapahtumamyynnistä. Artikkelissani kysyn, millaisia ovat tällaisen torikaupan perinteet? Miten torikauppiaat kuvaavat elämää ja kaupantekoa torilla?

Kesällä 2014 tein kenttätöitä torilla haastattelemalla nykyisiä ja entisiä kauppiaita. Omat juurenikin ovat torilla: kahdeksankymmentäluvun lopulta alkaen vietin torilla lähes kymmenen kesää myymällä mansikoita. Myös kesällä 2014 olin toisinaan myyjänä aitopaikalla havainnoimassa toria ja torin elämää. Omat kokemukseni antoivat mahdollisuuden tarkastella toria sisältäpäin, myyjien ja kauppiaiden näkökulmasta. Taustani auttoi myös luomaan luottamuksellisen suhteen haastateltaviin 
ja löytämään tutkimukseen sopivia haastateltavia. Pohdin artikkelissani myös "sisäpiiriläisyyttä", jonka oma kokemukseni tuotti. Useissa toreja käsittelevissä tutkimuksissa kuvataan sitä, kuinka myyjiin saadaan luotua luottamuksellinen suhde ja miten "torille ja kaupanteon verkostoihin päästään sisään" (ks. esim. Bestor 2004; Black 2012; Shepherd 2007; Morales 2009). Itse olin jo ennen tutkimusta oman taustani vuoksi torilla "sisällä". Olin silti samalla myös vieras sekä kokemusteni ajallisen etäisyyden että tutkijapositioni kautta (ks. esim. Fingerroos 2006; Lähteenmäki \& Ruotsala 2006).

Torit ovat kiinteä osa kaupunkikuvaa (Black 2012, 3). Toreilla yhdistyvät kulttuuriset, historialliset, taloudelliset, institutionaaliset ja sosiaaliset elementit, siinä missä paikalliset ja "kulinaarisetkin" tekijät, jotka liittyvät aina torien tarjoamaan tuoreeseen ja paikalliseen ruokaan. Torit ovatkin usein paikallisen ruokakulttuurin solmukohtia. (Ks. Bestor 2004, xiv.)

Theodore C. Bestor $(2004,20)$ määrittelee torin vaihdon, sosiaalisten toimijoiden, organisaatioiden, tuotteiden, kaupanteon käytäntöjen ja kulttuuristen merkitysten paikaksi, jossa suuri määrä erilaisia toimijoita kohtaa. Tori on tietyssä fyysisessä sijainnissa oleva taloudellinen ilmiö sekä sosiaalinen kehys, joka on sekä tilallinen että säännelty. Toreilla on omat sääntönsä, jotka rajaavat kaupantekoa myyntipaikkojen ja aikojen suhteen. Toisaalta toreilla on myös omat lainalaisuutensa tietynlaisena sosiaalisena miljöönä. Torikaupalle luonteenomaista ovat kiinteät sosiaaliset suhteet. Usein torikauppa onkin perheitten ja sukujen ylläpitämää. Toreja määrittelevät myös ystävyyden, tuttuuden, poliittisuuden, hyödyntavoittelun ja talouden verkostot. (Ks. esim. Bestor 2004; Shepherd 2007; Black 2012.)

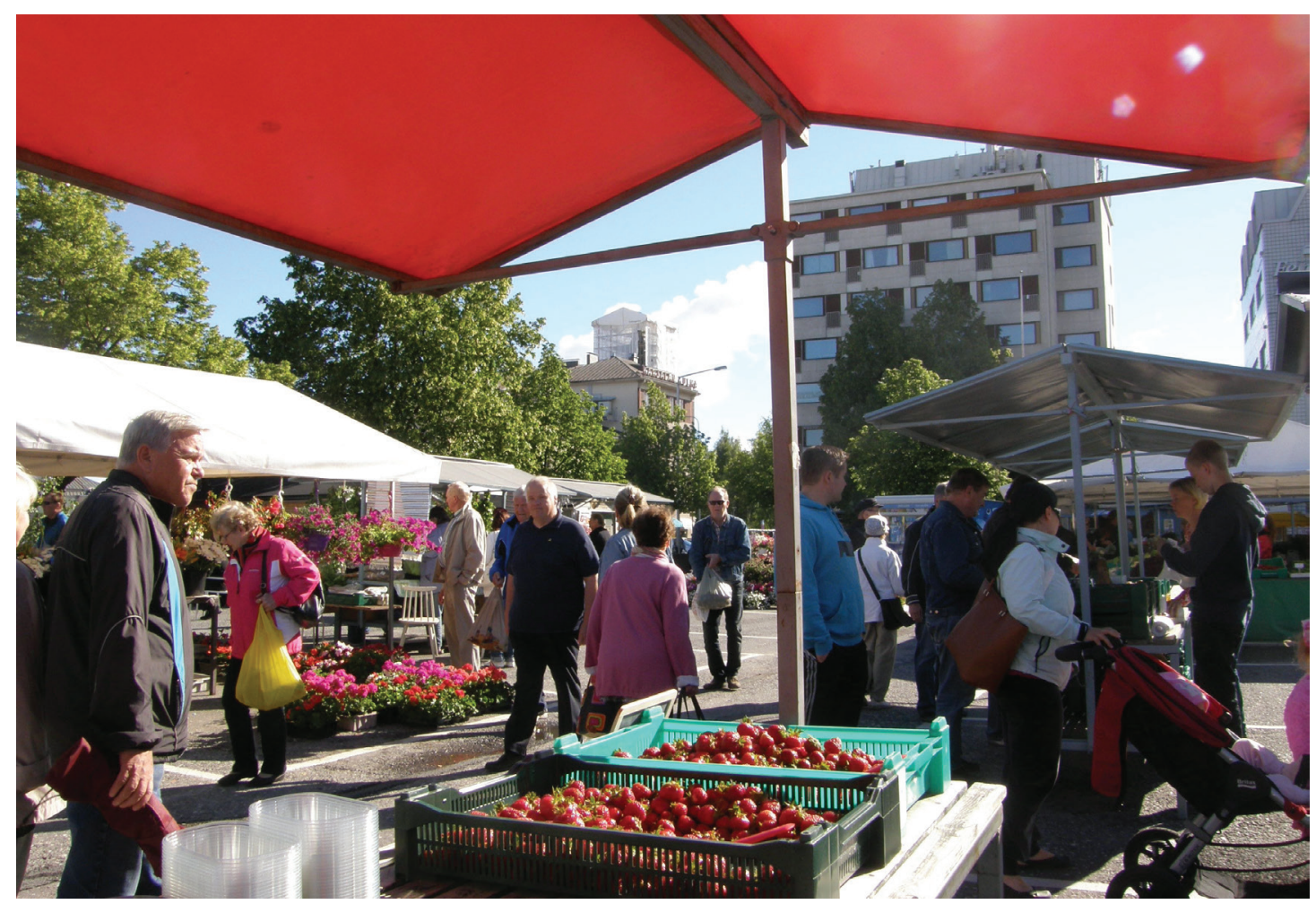

Kuva 1. Juhannus torilla 2014 tiskin takaa. Kuva: Sari Tuuva-Hongisto. 


\section{MIKÄ ON TORIKAUPPAA?}

Suomalaista markkinakauppaa on tutkittu jonkin verran (ks. esim. Varsta 1946; Heinonen 1984), mutta torikauppa arkisena ja päivittäisenä on jäänyt tapahtumarikkaiden ja mieleen painuvien markkinoiden jalkoihin. Markkinakauppa ja torikauppa poikkeavat toisistaan. Markkinat tapahtumana kokoavat laajalta alueelta ympäri Suomen kauppiaita, jotka päätyönään kiertävät tapahtumia. Markkinoita järjestetään tiettyinä ajankohtina, jotka vaihtelevat paikkakunnittain. Yleensä markkinat järjestetään syksyisin ja keväisin. (Heinonen 1984, 27.) Torikauppiaat sen sijaan pysyvät paikallaan ja ovat leimallisesti jonkun tietyn torin kauppiaita, jonka ympärille on vakiintunut tietty asiakaskunta. Kauppiaat voivat olla laajalta alueelta, mutta pääosin he ovat kuitenkin lähikunnista. Torikauppa on luonteeltaan pysyvää ja perustuu vakituisiin kauppiaisiin ja vakituisiin asiakkaisiin. Torikauppaa tehdään päivittäin, samalla paikalla, kaupungin torilla.

Torimyynti on perinteisesti tuottajien ja viljelijöiden omaa myyntiä (Black 2012, 3). Torilla kauppaa tekevät tuottajat vuokraavat torilta myyntipaikan, jossa myyvät omia tuotteitaan. Myyntipaikan voi varata päiväksi tai jopa kokonaiseksi vuodeksi. Torien myyntiaika painottuu aamuun: perinteinen torien aukioloaika on 7-14, arkisin ja lauantaisin. Myyntipaikat on torilla luokiteltu sen mukaan, mitä ja miten niissä myydään. Torikauppa on säädeltyä ja säänneltyä aina tuotteiden alkuperän merkitsemisestä myyntikojun ulkoasuun.

Lappeenrannassa torikauppaa tekevät erityisesti ympäristöseudun viljelijät, jotka käyvät torilla myymässä omia tuotteitaan, kuten perunoita, marjoja, vihanneksia ja kukkia. Viljelijöiden suoramyynnin vankka asema on yksi Lappeenrannan kauppatorin omaleimainen erityispiirre, jäänne, joka nykyisin oikeastaan muodostaa kauppatorin myynnin perustan kahvikioskien ohella. Muun tyyppinen torimyynti kuin viljelijämyynti ei ole vuosien saatossa säilynyt ja jatkanut perinteitään. Toisaalta "maalaismyyjät" eivät itsekään miellä itseään torikauppiaiksi, kuten perunakauppias asian tiivisti: "No en mie silleen että olis torikauppias, maatalousyrittäjä ehkä mieluummin, et se on niin monimuotosta, että ei pelkkä torikauppias, sie viljelet, markkinoit sen ja sie teet sen kaiken, et siin on iso työ."

Kansatieteilijä Merja Kokkonen on tutkinut Lappeenrannan torikauppaa 1930-luvulta 1970-luvulle. Kokkosen vuonna 1985 tekemässä tutkimuksessa torikauppaa tarkastellaan tori-ja hallikauppana, vakituisena ympärivuotisena ja ammattimaisena torikauppana kauppatorilla. Sellaisenaan torikauppaa ei varsinaisesti enää ole. Vakituisia ammattimaisia torikauppiaita, joita Kokkosen tutkimus käsittelee, ei Lappeenrannan kauppatorilla ole enää muita kuin hallikauppiaat ja kahvikioskimyyjät. Viljelijöiden ja tuottajien sesonkeihin sijoittuvan oman myynnin tutkimus sivuuttaa, sillä se on luokiteltu tilapäiseksi myynniksi erotuksena ammattimaisesta torikaupasta. Tuolloin ammattimaisiksi torikauppiaiksi luetut lihakauppiaat, kotiteollisuuskauppiaat, tekstiili- ja rihkamakauppiaat ja kalakauppiaat eivät enää tänä päivänä toimi torilla (ks. Kokkonen 1985, 44).

Vihanneksia, juureksia ja marjoja toreilla myyvät myös välittäjäkauppiaat, jotka ostavat tiloilta tai tukusta tuotteet ja myyvät ne torilla eteenpäin. Välittäjiä 
Lappeenrannan kauppatorilla toimii nykyisin kaksi. Vielä seitsemänkymmentäluvulla välittäjiä oli kolmetoista, satamatorin aikaan kolmisenkymmentä. Välittäjien eli "jobbarien" myynti on nykyisin keskittynyt markettien edustoille ja tapahtumiin, ei niinkään torille. Myös tekstiilikauppa on muuttunut. Tekstiili- ja rihkamakauppiaat, jotka olivat torilla vielä 1970-luvulla, ovat lopettaneet. Nykyisin tekstiilejä ja tavaraa myyvät pääsääntöisesti kiertävät kauppiaat ja markkina- ja tapahtumakauppiaat. Kauppiaissa on myös runsaasti ulkomaalaistaustaisia, jotka samalla tekevät maahantuontia. Lappeenrannassa tekstiili- ja rihkamakauppaa tehdään nykyisin erityisesti satamatorilla, jossa myyntiä on mahdollista tehdä iltaisin aina myöhään yöhön asti.

Kurttila ja Pennanen $(1992,95)$ näkevät torikaupassa kaksi eri suuntausta, perinteisen ja "modernin". Perinteisessä torikaupassa kauppiaiden myyntiartikkelit ja elintarvikkeet ovat usein itse tuotettuja tai tehtaalta suoraan ostettuja pieniä eriä. Näillä myyjillä on usein pitkä kauppiasperinne takanaan ja oma vakituinen asiakaskuntansa. "Modernit" markkinakauppiaat heijastavat muuttuvaa yhteiskuntaa. Heidän myyntiartikkelinsa on enimmäkseen tuotu suoraan ulkomailta ja tavaravalikoima muotoutuu ja muuttuu ostajakunnan ja vuodenaikojen mukaan. Myynnin ohella etsitään uusia artikkeleita ja haetaan uusia ostajaryhmiä, kuten nuorisoa. Näillä kauppiailla saattaa olla myös omaa maahantuontia ja tukkumyyntiä.

Usein juuri tuottajien torimyyntiä pidetään perinteisenä, toisinaan myös jäänteenä menneestä. Viljelijöiden myynnillä on vuosisataiset perinteet (Black 2012, 143.) Keskityn tutkimuksessani tähän perinteiseen kaupanteon tapaan, viljelijöiden ja alkutuottajien kaupanteon perinteeseen, myyjiin, joiden kaupanteko on säilynyt Lappeenrannassa katkeamattomana useita sukupolvia. Pitkälti heidän ansiostaan Lappeenrannan kauppatori on säilynyt niin elävänä kauppapaikkana nykypäiviin asti.

\section{Metodologinen tausta}

Metodologisesti tekemäni tutkimus linkittyy etnografiseen muistitietotutkimukseen, jossa lähtökohtana on muistitiedon sekä etnografisen tiedon dialogisuus ja neuvottelunvaraisuus (Makkonen 2009). Etnografisen tutkimuksen tavoitteena on kuvata ja selittää inmisten toimintaa, tulkintoja ja käsityksiä ympäristöstään ja toiminnastaan. Etnografialla pyritään kokonaisvaltaiseen ymmärtämiseen ja kuvaamiseen ja sen lähtökohdat perustuvat inmisten ja ympäristön monipuoliseen havainnoimiseen. Havainnoiminen tapahtuu yleensä fyysisenä läsnäolona ihmisten ympäristössä ja konkreettisissa vuorovaikutustilanteissa tutkittavien ihmisten kanssa. (Lappalainen 2007.)

Nykyhetki muovaa sitä, mitä muistetaan ja miten kerrotaan. (Fingerroos \& Haanpää 2006.) Tulkinnallisen muistitiedon tavoitteena on menneisyyttä käsittelevän muistitiedon ja menneisyyden merkityksen ymmärrettäväksi tekeminen, ei aukoton menneen kertaaminen. Muistelussa korostuvat muistelijoiden omat tulkinnat siitä, mitkä asiat ovat muistamisen, kertomisen ja säilyttämisen arvoisia. (Makkonen $2009,13$.$) Muistitieto kertoo eletystä, koetusta ja arkisesta ja merkitykset raken-$ tuvat vuoropuhelussa muistelijan ja kuulijan välillä. Muistitieto on luonteeltaan 
erityistä tietoa, ja se kertoo vähemmän menneisyyden tosista tapahtumista kuin siitä, mikä näiden tapahtumien merkitys oli tai on muisteluhetkellä. Muistitiedon rinnalla puhutaan myös kulttuurisesta muistista, jolla tarkoitetaan sekä muistia ja yksityistä muistamista, mutta myös symbolisia järjestyksiä, mediaa, instituutioita ja käytäntöjä, joilla sosiaaliset ryhmät muokkaavat jaettua mennyttään ja jaettua yhteistä muistiaan. (Erll 2008, 2-5.) Tarkastelen toria tässä artikkelissa koettuna ja elettynä paikkana, jota tuotetaan puhumalla ja muistelemalla. Tori on eräänlainen muistin paikka, jonka muisteluun kytkeytyy rikas suullinen perinne ja puhekulttuuri, jota ovat ylläpitäneet niin kauppiaat kuin kaupunkilaisetkin. Se kiinnittyy paikkaan, mutta on samanaikaisesti osa laajempaa kerrontaa ja muistelua. Siihen liittyy henkilötarinoita, kaskuja, juttuja ja tarinoita sekä myyjistä että kaupunkilaisista. Muistin paikan ominaisuuksiin kuuluu, että se yhdistää tietyn yhteisön jäsenet muistelemaan ja tulkitsemaan menneisyyttä ja uudistamaan tietoisuutensa historiasta. Muistin paikat tukevat kommemoraatiota eli yhteisön menneisyyden, nykyisyyden ja tulevaisuuden välisen yhteyden ymmärrystä ylläpitävää muistelemisen käytäntöä. (Sivula 2013; Nora 1998.)

Tein tutkimukseeni haastattelujen lisäksi myös kenttätyötä ja havainnointia sekä osallistuin torin elämään sekä kauppiaana, asiakkaana että tutkijana. Kävin laajasti lävitse erilaista toriin liittyvää tausta-aineistoa, joka koostui paikallishistorioista, historiikeista, lehtiartikkeleista, kaunokirjallisuudesta ja nettikeskusteluista. Pyrin tuottamaan aineistosta "tiheän kuvauksen", jossa tavoitteena on ymmärtää kulttuurisia ja sosiaalisia merkitysrakenteita, ei ainoastaan kuvata kohdetta niin kuin tutkija sen näkee (Geertz 1973; Kortelainen 2008, 34). Etnografiseen otteeseen liittyvät myös tulkinnallisuus ja refleksiivisyys sekä tutkijan oman paikantumisen pohtiminen. Tutkimusten avauskertomusten "siellä oleminen" ja "täällä oleminen" paikantavat tutkijan kentälle (Aro 1996, 29; Fingerroos 2003). Tutkijana en myöskään pelkästään havainnoinut toria: kuuluin myös itse kenttään, osallistuin sen elämään ja siitä tehtäviin tulkintoihin (ks. esim. Korjonen-Kuusipuro \& Kuusisto-Arponen 2017). Vaikka tekemäni muistitietotutkimus pohti laajemmin torin menneisyyttä sekä muistitietoa ja menneen kertomista, on tämän artikkelin pääpainona tarkastella torikaupan tekemisen kulttuuria. Tästä syystä aineistoa käsitellään lähinnä etnografisen kuvauksen kautta: haastateltavat kuvaavat ja kertovat torikaupasta, jota tekevät ja ovat tehneet vuosikymmenien ajan.

\section{KentTÄTYÖSSÄ TORILLA}

Kävin torilla säännöllisen epäsäännöllisesti asiakkaana, tutkijana ja myyjänä. Kävin jututtamassa aamun kahviporukoita, olin juhannusaaton sekä muutaman muun päivän mansikanmyyjänä, istuin vedyllä ja kahvilla, valokuvasin, olin asiakkaana ja jututin myyjiä. Tein ensimmäisen varsinaisen kenttätyöpäivän toripöydän takana juhannusaattona 2014. Juhannusaatot ovat torimyynnin ehdoton kohokohta. Olin käynyt jo keväällä ja alkukesästä torilla, mutta huomasin, että kentälle oli vaikea päästä sisään. Tori ei auennut vain torilla käymällä ja kahvipöydässä istuskelemalla. Oli tärkeää päästä toripöydän taakse (ks. myös Shepherd 2007; Black 2012; Bestor 2004). Toripöydän takaa näkee torin parhaiten ja se oli myös positio, josta käsin olin itsekin tottunut toria tarkkailemaan ja havainnoimaan. 
Tori oli juhannusaattona täynnä, myyjiä oli sadan kieppeillä ja tori tuntui täydeltä. Väkeä oli tungokseen asti. Myynnissä oli juhannuksen herkkuja, mansikoita, perunoita, leipiä ja leivonnaisia, vihanneksia, kasviksia, savukalaa, rinkeleitä, vastoja, kukkia, hunajaa, käsitöitä, koreja, tekstiilejä ja rihkamaa eli kaikkea mahdollista. Juhannuksena paikalle tulevat kaikki kynnelle kykenevät. Kesälauantaisin myyjiä on yleensä noin 50-80, kun tavallisina arkipäivinä kesällä heitä on vain 20-50.

Lappeenrannassa on vankka perinne käydä juhannusaattona torilla ja silloin torilla onkin kuhinaa. Torilta haetaan uuden sadon herkut ja käydään syömässä vedyt ja atomit. Näin oli myös kesällä 2014. Kahvikioskit olivat tupaten täynnä ja niihin jonotettiin. Tori oli koristeltu juhannuskoivuilla ja torilla oli useampikin katusoittaja. Eräs asiakas ehti kertoa, että koko muu kaupunki oli autio, eikä satamassa ollut ristinsielua. Toinen, reilu kolmikymppinen perheenisä, puhkui intoa kädet täynnä nyssyköitä, kun oli saanut jo heti aamutuimaan ostettua juhannuksen herkut: oli perunoita, tilliä, salaattia, leipää, rinkeleitä, savukalaa, juustoja hallista ja tuore koivuvasta, vielä mansikat puuttuivat. Ostosten jälkeen matka suuntasi vedylle. Asiakkaista vanhukset erottuvat suurimpana yksittäisenä ryhmänä ja ehkä enemmän kuin muualla kaupunkikuvassa torilla tapaa rollaattoreja, juhannuksenakin useasta rollaattorista törrötti vasta ja sangassa roikkui perunapussi.

Tarkoituksena oli, että menisin torille aamusta kahdeksaan ja olisin aamun myymässä yksin mansikoita. Kymmeneltä jatkaisimme kahdella myyjällä. Tavallisesti paras myynti on noin kymmenen-yhdentoista aikaan ja hiljenee puolenpäivän jälkeen. Toisin kävi, sain lastin myytyä kahdessa tunnissa. Asiakkaita oli lähes koko ajan jonoksi asti ja kauppa kävi kuin siimaa. Tottumattomalle kiivas myyntitahti oli rankka, tein virheitä, jopa niin että asiakas joutui huomauttamaan, että laskin väärin rahasta takaisin. Nopea ja tarkka laskutaito oli ruosteessa ja huomasin, että repliikit eivät aina tulleet selkärangasta kuten aiemmin. Keskittyminen ja fokus eivät tahtoneet pysyä kasassa, kun asiakkaat huutelivat tai kyselivät sivusta samalla kun olin esimerkiksi laskemassa toiselle asiakkaalle rahoja. Mutta asiakkaiden repliikit olivat ennallaan: "onks nää sielt Lemi etiält iso kive takoa?", "nii on posket punaset kuin marjatkin". Myös yksi kosinta osui aamuun.

Aamun aikana sain myös yhden haastateltavan, joka oli kuullut, että olen tekemässä tutkimusta torista. Hän halusi kertoa torimyynnin muistojaan satamatorilta. Jutellessani ihmisten kanssa pidin myös toisinaan nauhuria päällä ja otin valokuvia ja annoin muutamille käyntikortin, jossa oli hankkeeni sähköpostiosoite ${ }^{1}$ ja yhteystietoni. Käytännössä päivä oli kuitenkin enemmän myyntipäivä kuin kenttätyöpäivä - en ollut torilla tutkijana vaan myyjänä. Olin etukäteen ajattelut, etten sekoittaisi näitä rooleja, mutta huomasin, etten voinut mennä torille vain tutkijana, varsinkaan kun taustani oli torilla.

Tiukan myyntisession jälkeen suuntasin itsekin vedylle ja kahville ja tein ostoksia juhannusta varten. Juhannuksen jälkeen opastin uuden marjanmyyjän myyntipaikalle ja myöhemmin kesällä kävin toisinaan tuuraamassa torilla. Pääosan kontakteista haastateltaviin sain torilla, ja tein myös muutamia nauhoitettuja haastatteluja.

1 Käytin aineistokeruussa sähköpostiosoitetta: torimuistot@gmail.com 
Sari Tuuva-Hongisto: Kaupanteon perinteitä Lappeenrannan kauppatorilla

[http://www.elore.fi/arkisto/2_17/tuuva-hongisto.pdf]

Enimmäkseen tein haastattelut kuitenkin haastateltavien kotona syksyllä sesongin päätyttyä, sillä en halunnut vaivata heitä kesken kiireiden. Syksyn ja talven mittaan kävin torilla paljon myös asiakkaana, jutustelin myyjien kanssa niitä näitä ja kirjoitin jälkikäteen muistiinpanoja, esimerkiksi seuraavasti:

Syksyinen perjantai. Kauppiaita paikalla kolmisenkymmentä, puolipilvinen harmaa syksyinen sää. Paljon kukkia ja vihanneksia, mustikoita ja kanttarelleja. Tein itse toriostoksia ja juttelin samalla muutamien kauppiaiden kanssa. Kanttarelleja, mustikoita ja kukkia myynyt Juha kertoi olleensa torilla pikkupojasta asti. Myi kukkia ja itse keräämiään marjoja ja sieniä, niin kuin aina, jo vuosia.

Hunajakauppias on perustanut yrityksensä 28 vuotta sitten, käy torilla ja kiertää myös markkinoita, ja käy myös sunnuntaisin kirpputorilla myymässä. Silloin parhaimmillaan myyjiä saattaa olla parisataa, mutta on myös ollut niin, että oli vain kaksi muuta myyjää paikalla. Tavallisesti kesäaikaan perjantaisin ja lauantaisin torilla myyjiä on kolme-neljäkymmentä. Kahvikojut vetää hyvin ja ensimmäinen rivi, jota joskus, varsinkin aiemmin kun venäläisturisteja oli runsaasti, kutsuivat nevski rospektiksi. Turisteilla varsinkin on tapana liikkua vain ensimmäisellä käytävällä, jossa hunajakauppias nytkin oli. Paikalla ei kuulemma kuitenkaan ole niin kovin suurta väliä. Kirpputorikauppiaat tulevat edelleen varaamaan paikkoja jo kolmen jälkeen, hän itse tulee kuuden maissa, ja se kuulemma on, ainakin muiden mielestä, liian myöhään. Lähiruuasta on kiinnostunut vain 5 prosenttia nuorista. Miten ne loput 95 prosenttia saisi kiinnostumaan torista ja tuoreesta ruuasta?

Hunajakauppias puhui myös amerikkalaisesta farmer's market ideasta, jossa olisi katettu käytävä ja sen varrella suoraan autoista parkkeerattavat myyntipöydät. Voisiko tori olla myös sellainen? Miksei Lappeenrannassa osata nähdä toria matkailullisena? Kaikki kuitenkin aina matkoillaan kertovat käyvänsä toreilla ja turistejahan täälläkin käy. Torin potentiaali ehkä vähän unohdettu. (Ote kenttätyöpäiväkirjasta 22.8.2014.)

Torilla käy vuosittain satoja kauppiaita ja tuhansia asiakkaita. Osalle myyminen on vakituinen, joillekin osa-aikainen työ, joillekin silkka harrastus. Jotkut myyjät ovat torilla lähes ympäri vuoden ja joka päivä, jotkut muutamia päiviä kesässä. Toisilla on torilla pitkä historia, toiset ovat olleet muutaman vuoden tai ensimmäistä kesää. Toiset myyvät itse, toisilla on palkattuja kesätyöntekijöitä. Kauppaa tekevien joukko on kirjava, sillä vakituiseksi luonnehdittavia kauppiaita oli vuonna 2014 noin kolmisenkymmentä. Tutkimuksessani etsin haastateltaviksi lähinnä sellaisia henkilöitä, joilla oli pitkä historia torilla. Tapasin kesän aikana suurimman osan torin kauppiaista, esittäydyin, annoin yhteystietoni ja kerroin tutkimuksestani. Tällä tavoin sain kontaktin suurimpaan osaan tutkimukseeni suostuneista ja osallistuneista haastateltavista. Pyysin myös heitä suosittelemaan sopivia haastateltavia. Osa haastateltavista on myös ottanut minuun yhteyttä. Joitakin nauhoitettujakin haastatteluja tein torilla, mutta suurinta osaa haastattelin heidän kotonaan. Nauhoitettuja laajoja haastatteluja on tehty 18, ja yhteensä haastateltavia on 24. Aineistossa on lisäksi kaksi ryhmähaastattelua sekä tilannenauhoitus Lappeenrannan Killan järjestämästä kauppatoriaiheisesta keskustelutilaisuudesta.

Ensisijaisen aineiston muodostavat tutkimuksessani avoimet, nauhoitetut haastattelut. Haastatteluissa käytin apuna valokuvia, sillä toria on julkisena tilana kuvattu paljon. Vanhat kuvat sekä valokuvakirjojen kuvaukset torista loivat haastatteluihin 
ajallista kontekstia, kuvien avulla oli helppo päästä kiinni aiheeseen ja sijoittaa itsensä menneeseen (ks. Kortelainen 2008, 66-67). Toisaalta myös haastateltavien omat valokuvat ja erityisesti lehtileikkeet toimivat haastatteluiden ajallisena runkona. Useista haastatelluista oli kymmenittäin lehtijuttuja vuosien varrelta. Haastatelluilla oli laajoja lehtileikealbumeja, joihin he olivat koonneet uransa aikana tehtyjä lehtikirjoituksia. Monilla torikauppiailla oli selkeästi oma julkisuutensa, joka oli tärkeä "oman brändin" luonnissa. Tori onkin julkinen tila, ja torilla kauppaaminen on tietynlainen rooli ja performanssi, jossa jokainen myyjä on oman torinsa ja asiakaskuntansa napa. Useat haastateltavat olivat tottuneita kertojia ja haastateltavia: he kertoivat tarinansa niin kuin olivat kertoneet ennenkin, haastattelijalle, ostajille, toisilleen ja asiakkaille. Torikauppiaat olivat tässä mielessä "helppoja" haastateltavia ja hyviä kertojia, tottuneita puhujia: "tuppisuut ei täällä pärjää."

Tutkimus on paitsi lähteiden keruuta myös niiden tulkintaa. Tulkinta alkaa lähteiden valitsemisesta, jatkuu haastattelijan roolissa ja kulminoituu tutkimuksen lopullisessa esittämisessä tekijän äänellä ja haastattelukatkelmien valinnoissa. (Portelli 2012 , 47.) Vaikka muistitieto sisältääkin runsaasti muiden ihmisten kanssa yhteistä ainesta, muistelijat ja kertojat ovat aina yksittäisiä inmisiä, jotka ottavat vastuulleen ja tehtäväkseen muistaa ja kertoa muistamastaan (Mts. 42). Monet tutkimuksen haastateltavista olivat taitavia kertojia, sillä usein he, jotka ottavat tehtäväkseen kertoa, ovat myös eräänlaisia spesialisteja ja taitureita, jotka pystyvät poimimaan "elämän jatkuvasta virrasta juuri ne sanat, tilanteet ja teot, joissa on komiikan, tragedian tai mielettömyyden ainesta" (Ukkonen 2000, 28).

Tori muodostaa selkeän moraaliyhteisön. Kauppiaat välttivät puhumasta toisistaan ja olivat varovaisia henkilökohtaisen juoruilun suhteen. Taina Ukkosen $(2000,152)$ mukaan menneisyyden kertaamisen yhteydessä muistelijat tavallisesti käsittelevät sekä yksittäistapauksia tai omia kokemuksia että tekevät yleistyksiä ja tuovat esiin miten asiat heidän käsityksensä mukaan yleensä ja normaalisti ovat. Torilla kauppiaat sen sijaan välttivät tekemästä yleistyksiä ja toimivat tässä mielessä tavanomaisesta poiketen. Kauppiaat olivat tietoisia siitä, mitä julkisesti halusivat kertoa. Toisten tekemisiä ei julkisesti haluttu kommentoida sosiaalisen paineen ollessa voimakas, jopa yleistyksien suhteen. Torilla jokainen pitää huolen omista asioistaan.

Suurin osa jututtamistani kauppiaista ei muistanut minua entuudestaan, vaikka olinkin ollut torilla lähes kymmenkunta vuotta. Se, että tori oli minulle tuttu, oli kuitenkin etu, ja monet haastateltavat pitivätkin tätä tärkeänä. Sisäpuolisuus antoi ymmärrystä torin erityisyydestä. Monet kauppiaat kokivat, että torikauppaa ja toria ei ymmärretä. Erityisen ajankohtaiseksi tämän kohtaamattomuuden tekivät kaupungin suunnitelmat torin kehittämiseksi. Tori ja kaupunki olivat kiistelleet torin kehittämisestä vuosikausia, ja kiistely oli erityisen ajankohtaista tutkimuksen teon aikoihin (ks. Tuuva-Hongisto 2017, 128-143.) Tämä myös osaltaan suuntasi tutkimustani ja oli usein myös syynä siihen, miksi niin monet torilla suhtautuivat tutkimuksen tekemiseen suopeasti ja halusivat tulla haastatelluiksi. He halusivat oman äänensä kuuluviin. Torin yllä leijui tuhoutumisen uhka, oli tärkeä saada "torin tarinat talteen" nyt kun se vielä oli mahdollista. 


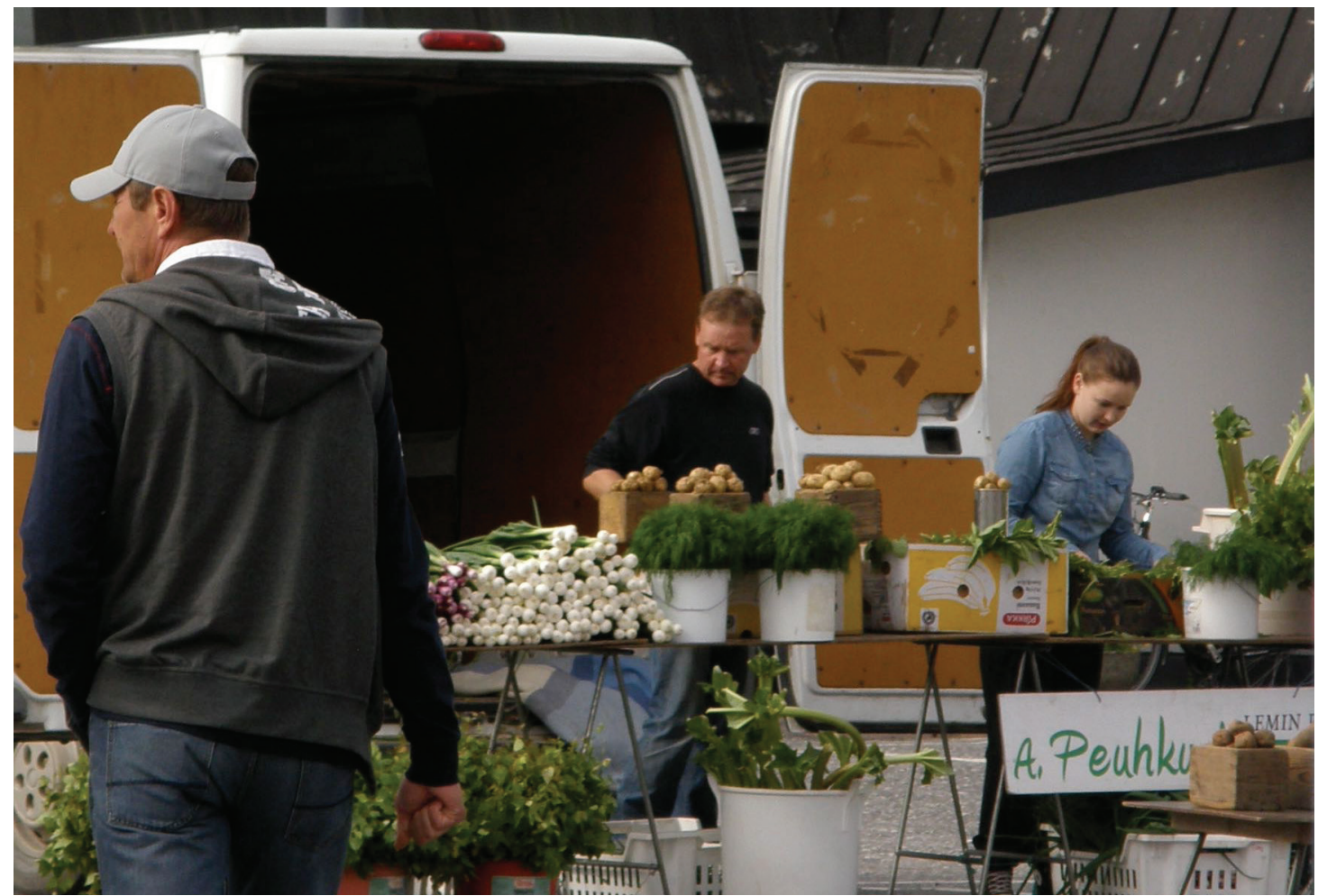

Kuva 2. Perunakauppaa torilla juhannuksena 2014. Kuva: Sari Tuuva-Hongisto

\section{KaUpanteon PERINNe}

Useimmat jututtamistani myyjistä kertoivat kaupankäynnin sukupolvista ja perinteestä. Torikauppiaat paikantavat itsensä torille yleensä kertomalla taustastaan ja torikaupan toistuvuudesta. Aloittaessani tutkimusta ja jututtaessani myyjiä he tavallisesti kertoivat siitä, kuinka pitkään he olivat tehneet torikauppaa. Kertomus torikaupan perinteestä on kauppiaiden vakiintunut avauskertomus, jota kerrotaan toistuvasti. Pitkät perinteet torilla ja vuosikymmenten kokemus ovat keino vakuuttaa ostaja laadusta ja taidosta. Se on myös tapa paikantaa itsensä torille ja torikauppaan. Perinne torikaupassa on tietynlainen vakuus siitä, että on luotettava ja hyvä kauppias.

Joskus sillo talvellakii joskus mitähän se olis ollu, kuuskytlukua, ni myö olti siskon saunavastoja ja lyhteitä myymäs täs torilla isän mukana. Et en muista mitä isä sit, mut myö oltii mukana myymässä niitä. Isä oli pikkupoikan itekii, Viipuris ku oli $\mathrm{ni}$, näitten saunavastojen kanssa ni saunojen vieressä myymässä. Ukot ku meni saunaan ni ne osti sit saunavastan. Et miekii oon ikäni aika jotai pientä kauppaa napostellu. Se on vähän niinku, se on perinne, se on menny tuonne takaraivoon ni se on siellä. (Haastattelu 13.8.2014.)

Kaupanteon kuvataan olevan usein synnynnäistä tai jo lapsena omaksuttu asenne. Kaupantekoa opetellaan ja harjoitellaan käytännössä torilla. Kaupallisesta koulutuksesta kaupanteon taustana kauppiaat eivät kerro. Ilmeisesti opiskelua pidettiin kaupanteon taidon oppimisen kannalta merkityksettömänä. Sen sijaan suvun 
ja perheen merkitys torikaupan taustana toistui kauppiaiden kertomuksissa. Kaupantekoon on kasvettu lapsena, jolloin on kuljettu vanhempien tai isovanhempien matkassa torilla. Myymistä on ensin harjoiteltu jollakin pienellä myytävällä, kuten kieloilla, vastoilla, kastemadoilla tai saunasormuksilla.

Alotin 61 , olin sillo 18 , jäin koukkuun. Kato tää torimiljöö, tääl kohtaa inmisiä, laiasta laitaa, tykkään täst hommasta, täst pitää tykätä ei tää homma muuten kule, semmonen välitön touhu, huumoria pitää olla sekaan. Et neljännespolves mitä tääl ollaa, äiti, minä, poika ja pojanpoika. Meil on yks potatkappa tuhattakaheksasataa kruunattu, et sil on vissii käyty Viipurin torilla. Semmosta tää touhu on. Tähä pitää olla mielenkiinto, ei täst muute tuu mitää, et kaikista ei oo torikauppiaiks.

Se vaatii sellasta pientä joustavuutta, pitää jokaine asiakas ottaa omana ittenää, tääl on monenlaista ihmistä. Pitää kuunnella asiakasta enemmäkii, et mitä asiakas on mieltä. (Haastattelu 7.8.2014.)

Myyjät korostavat, ettei kaikista ei ole torikauppiaiksi. Myynti vaatii tietynlaisen luonteen. Monet puhuvat elävyydestä, puheliaisuudesta, huumorista ja joustavuudesta. Asiakkaita on moneen lähtöön ja monenlaisten inmisten kanssa on tultava toimeen. Vaikka supliikki on kaupanteolle tärkeää, on erityisen tärkeää myös kuunteleminen ja tietynlainen avoimuus ja vastaanottavuus. Myyjät esimerkiksi saattoivat kertoa ja kuvata sitä, miten torilla tulee olla: myyntipöydän takana istuminen tai oleminen kädet puuskassa on torjuvaa, mutta seisominen avoimessa asennossa ja hymyily kuuluvat myymisen aktiivisuuteen. Myös kehonkielellä on merkitystä vuorovaikutuksen luomisessa.

Ja jos ne näkee et joku toine myy, se on tavarasta kiinni. Nii. Ei se ole. Ja henkkohtane minkälaine on kanssakäynti on asiakkaan kanssa. Jos seisoo näi (torjuvasti), ni ei varmast tuu. (naurua) Et se on oltava ihan niinko, et juttelee asjakkaitten kanssa ja hymyilee, ni se on kaikist ja sanoo päivää. mm. Et se on kaikista myyvin semmonen. (Haastattelu 1.10.2014.)

Torille on myös ominaista tietynlainen puhekulttuuri ja supliikki. Kauppa ei perustu markkinoista tuttuun huuteluun tai helppoheikkimäiseen myyntitapaan vaan pikemminkin luontevaan rupatteluun ja "haasteluun". Asiakas avaa keskustelun tavallisesti kysymällä hintaa, vaikka hintojen tuleekin aina olla näkyvissä.

Ko emäntä oli tuos myymässä yhen kerran ja siin ol yks vakituine asiakas käi siin ja sano, et sie oot paljo parempi kauppias, tuo siun mies on semmonen et se, se kyllä myöpi ja se jotai ain sanooki, mut sillo ko saap perunan pois, se sanoo hinnan ja sanoo kiitti hei. Ko emäntä on kova haastamaa, ni se piti ain pitkät tarinat sen mummon kanssa ja se sano, et paljo parempi kauppias sie olet. (naurua). Ko se siun mies on semmonen ku se saap rahat, ni se on kiitti hei. Nii hyväst se selitti. Ja niihän se, ja kun kauppa käi ni ei olt aikaa haastella. (Haastattelu 25.5.2015.)

Vuorovaikutukseen asiakkaan kanssa kuuluu olennaisesti kohteliaisuus, tervehtiminen ja leppoisa jutustelu. Robert Shepherd $(2007,114)$ on washingtonilaista Eastern Marketia käsittelevässä tutkimuksessaan kuvannut hyvän torikauppiaan imartelevan, puhuvan mukavia ja sanovan melkein mitä tahansa saadakseen tuotteensa myytyä. Lahjakas myyjä suorittaa rooliaan tauotta, ja myynti onkin hänelle eräänlainen performanssi. Roolin ja esityksen tavoitteena on vakuuttaa, luoda 
Sari Tuuva-Hongisto: Kaupanteon perinteitä Lappeenrannan kauppatorilla

[http://www.elore.fi/arkisto/2_17/tuuva-hongisto.pdf]

ostamiseen takuu ja turvallisuus, synnyttää luottamus kauppiaan ja ostajan välille. (Shepherd 2007, 133.)

\section{KAUPANTEON KULTTUURI}

Torimyyjät kuvaavat pieteetillä tuotteitaan ja niiden kasvattamista ja valmistelua myyntiin. Käsin tekeminen luo laatua. Pinaatit on kerätty käsin, perunat kaivetaan edellisenä iltana käsin kuokalla, kukkaniput on sidottu aamulla ennen torille tuloa. Myytävien tuotteiden laatu on tärkeää. Tuotteista ja tuotteiden laadusta kertominen on tärkeä osa kauppiaiden leppoisaa puhekulttuuria ja supliikkia.

Myö on hyvin saatu mänemään kukkaa, mutta sitäkin pittää olla niin paljon, että jos on kukkaa kolmessa ämpärissä, ni sitä et saa varmaan sitä yhtäkään ämpäriä myytyä, mutta jos sitä on kolmekymmentä ämpäriä, niin se kiinnostaa inmisiä ja ne jääpi sitä sitten kattomaa ja yritetään aina tälleen illalla kerätä ja eikös oo hyvännäköstä kukkaa?

Ne auringonkukat on ollu, kaks euroa kolme kukkaa ja saa valistella siitä itte kukat, nekin on otettu tänä aamuna ja näille on sitten se hoito semmonen että ku viijään kottiin ja pannaan enemmän suppusuiseen maljakkoon ja leikataan, niin siinä pitää ollaa valmiiks se kuuma vesi, se pitää olla kuuma ei kiehuva, mut se pitää olla että vähän tuntuu kuumalta, leikataan ja just sinne vetteen ja varjoon, ettei panna aurinkoon.

(Suuntaa puheensa ohikulkevalle asiakkaalle.)

Ja rouva tule ostamaan kukkia! Kolme euroo nippu, mie oon kaikki tehny tänä aamuna ja poika on tehny asterinippuja ja auringonkukkaa on kansa ja kahella eurolla saa kolme siitä. (Haastattelu 4.8.2014.)

Tein muutamia haastatteluja torilla. Niille yhteistä oli katkonaisuus asiakkaan sattuessa paikalle tai lähietäisyydelle. Edellä olevassa lainauksessa haastattelukerronta vaihtuu välillä myyntipuheeseen, jonka kohteena on ohikulkeva rouva. Torilla kauppiaan huomio oli jatkuvasti ympäristön havainnoinnissa ja mahdollisesti ostamaan tulevissa asiakkaissa. Tilanne ei ole haastattelun kannalta otollinen, sillä myyjät pyrkivät koko ajan kiinnittämään myös asiakkaiden huomion tarjoamalla tuotteitaan, vaikka asiakkaiden houkuttelu huutelemalla onkin vähäistä.

Pena: Kylhä tääl on yrittäny millo kukakii vuosien mittaa, ne tulee et tää on helppoa rahaa, et senku tulee vaan ja alkaa myymää. Mut jos ei oo asiakkaita ni, huono on. Tuppisuun. Tuppisuuna varsinkii jo oot ni ei tuu mitää. Mut tämmöne hölö ko myö ollaa, myöhä voijaan haastaa ihan mitä vaan.

Kalle: Se on muute muuttunu, et tänä päivänä ei pysty puhumaa ihmistä, siis ostamaa jos se ei halua ostaa, mut joskus takavuosina, alkuaikoina oli

Pena: Pitäs oikei kysyä, onks teijäkii äiti kieltäny juttelemasta vieraitten miehien kans, hä (naurua). Kerrohan Sari onks se kieltäny puhumasta vieraitten miehien kans, et jos toine tulee tarjoomaan jotaki ni (naurua), nii. Joo-o, ihan tuppisuuna kulkee ohi, ni taas on äiti kieltäny puhumasta vieraitten miehien kanssa, jostai syystä ne alkaa kiertämään tollee vähä kauempaa. Joku sanoo et tää on tää 
Sari Tuuva-Hongisto: Kaupanteon perinteitä Lappeenrannan kauppatorilla

[http://www.elore.fi/arkisto/2_17/tuuva-hongisto.pdf]

Lemi-Highway tää ku tulee perunamyyjien välii tuohon noin. (naurua). Siit jos selviää läpitte ni on aika tekijä (naurua).

Kalle: Kyllähän siitä selviää läpitte, mut sillo vielä kaheksankytluvulla ku oltii, oli asiakkaita, ni sillo piti kävellä läpite jos tuli mitä ostamaa. Ihmiset on muuttunu. Ostajat on muuttunut, inmiset tietää mitä haluaa. Mut sillo sai haluamaa.

(Haastattelu 10.10.2014.)

Torikauppiaat käyttävät edelleen litroja ja kappoja tai nippuja tarkkojen kilomäärien sijaan. Litrojen ja kappojen käyttö on osa torilla myymisen perinnettä ja siitä halutaan pitää kiinni. Mittaaminen asiakkaalle kuuluu kaupanteon tapaan ja on osa henkilökohtaista palvelua. Torilla hintojen pitää olla näkyvissä, mutta hinnoista myös pyöristetään ja käytetään paljousalennuksia. Erityisesti kauppiaat puhuvat reiluista mitoista ja siitä, kuinka tavaraa laitetaan aina vähän enemmän kuin on mitattu. Mittojen summittaisuus mahdollistaa reiluuden: reilu ja hyvä kauppias antaa enemmän kuin vain pyydetyn määrän.

Pena: Ja ykshomma et monikaa nuo kaupois käyvät ni ne ei niinku arvosta sitä torikaupas ko myyvään tätä tavaraa tästä vaik hinta ois vähä kovempi, mut meil laitetaan yleensä ain vähä lisää tavaraa siihe päälle, niinku kaupas, ni hinta on just se mikä on painokii. Mut myö laitetaa yleensä siihe lisää. Et tingitää näi päi

Sari: Tinkiiks asiakkaat minkä verran?

Pena: Kyllä, määrätyt mummot on hyviä tinkimää

Kalle: Kyllä, yläkanttii aina

Pena: Kauniit naiset saa aina paljon enemmä alennusta meiltä. (naurua)

Kalle: Kyllähän tinkiminen alkaa jäädä pois

Pena: Jos ymmärtäs vaa tinkiä.

(Haastattelu 10.10.2014.)

Tinkimiseen suhtaudutaan torilla ristiriitaisesti. Toisaalta se kuuluu torikulttuuriin, mutta toisaalta sitä pidetään epäsopivana. Monet myyjät odottavat myös asiakkailta kunnioitusta ja ystävällisyyttä. Torilla halpaa on bulkki, laatua pyritään myymään kalliimmalla ja torikauppa perustuu laatuun ja luotettavuuteen. Tinkiminen linkittyi esimerkiksi Shepherdin (2007) kuvaamalla washingtonilaisella Eastern Market -torilla aggressiiviseen bulkkituotteisiin liittyvään myyntitaktiikkaan, jossa tuotteita pyrittiin myymään laadusta välittämättä. Jotkut myyjät kertoivatkin antavansa alennusta silloin kun sitä ei pyydetty.

Torimyynnissä sekä myyjien että asiakkaiden väliset sosiaaliset suhteet määrittävät kauppaa siinä missä voiton tavoittelukin. Talousantropologi Stuart Plattnerin (1982) mukaan toreilla yleensä asiakkaat ja myyjät tuntevat toisensa, eivätkä he hae kaupasta pelkästään hetkittäistä henkilökohtaista taloudellista hyötyä. 
Sari Tuuva-Hongisto: Kaupanteon perinteitä Lappeenrannan kauppatorilla

Pikemminkin torikaupassa haetaan "hyväksyttävää sopimusta" tai sosiaalisten normien mukaista hyväksyttävää kauppaa sen sijaan että haettaisiin maksimaalista taloudellista hyötyä. Hyväksyttävä sopimus sisältää ajatuksen pitkäaikaisesta kauppasuhteesta, jossa sekä myyjä että ostaja pitävät yksittäistä kauppaa myös tulevana mahdollisuutena. Kaupasta muodostuu siis eräänlainen "tasapainottava vaihtosuhde". Kontrastina tasapainottavalle suhteelle on anonyymi vaihto, jossa haetaan maksimaalista hyötyä lyhyellä tähtäimellä. Torikaupassa päämäärä on aina pidemmällä, pitkäaikaisessa asiakassuhteessa. (Shepherd 2007, 54; Plattner 1982.)

No on, siihenhän se oikeestaan perustuukin (vakituisiin asiakkaisiin), et meil on aamul heti puol seittemältä ku aukee, ni aamupalaihmiset ja ketkä on heränny aikasi, et jotkut on heränny jo neljältä ja oottelee et pääsis kahville, ja sit on tää yheksän porukka. Niil on tämmönen ain sanovat et yheksän parlamentti, et sit siin päivän polttavat asiat siin keskustellaa. Et on semmonen, se on jännä, et tulee vähä, ollaaku vähän ku yhtä perhettä, et ne tulee sillai nii tutuiks et tietää heijän lapset ja lapsenlapset, monillakii on menossa, et kuinkahan monta polvee sellai, et mie oon palvellu niitä jo ku ne on ollu pieniä, et ne on nyt ite naimisissa ja niil on lapsia. Varmaa kaikil on tämmöset kanta-asiakkaat, niinko paikat, on tottunu käymään tietyssä ni sit on semmosii perheitä ja sit on kesävakkariasiakkaita, ketkä on kesät mökillä ni sit ne käy aina kauppareissulla, "myö taas tultiin", tai sit jos asuu ulkomailla ni sit ne sanoo et "myö taas tultii, nyt ollaa lomalla". Semmonen jännä, et on tullu semmosii todella pitkiä asiakassuhteita. (Haastattelu 6.11.2014.)

Torilla saattaa vaikuttaa siltä, että inmiset vain kiertelevät ja katselevat. Käytännössä torilla säännöllisesti asioivat kuitenkin pitävät yllä vakituisia asiakassuhteitaan. Torimyynti perustuu vakituisiin asiakkaisiin ja pitkiin asiakassuhteisiin: torikauppiailla on omat asiakkaansa ja asiakkailla omat kauppiaansa. Torilta ostetaan tuttuja tuotteita, samaa mitä on totuttu ostamaan ja mikä tiedetään hyväksi. Asiakassuhteet perustuvat luottamukseen ja vuosien tai jopa sukupolvien mittaiseen kauppasuhteeseen (ks. myös Ivanišević \& Belaj 2013). Asiakkaista pidetään hyvää huolta, sillä vakituiset asiakkaat ovat koko torimyynnin perusta. Toisaalta myös monille asiakkaille tutut, hyvät myyjät ja tuotteet ovat syy käydä torilla. Tori muodostaa tiheän sosiaalisen verkoston. Sosiaaliset siteet ovat tärkeitä luottamuksen rakentajia. Myyjät eivät ole vain abstrakteja kauppiaita, vaan yksilöitä ja persoonia, joiden kanssa jaetaan luottamuksellinen suhde. (Shepherd 2007, 110.)

Nyt yhtenä kesänä ku miul ol viel kukkaa enemmä tuol pellolla ja mie leikkasin kukkia, ja sit oli sellanen huono päivä siin torilla, et ei menny. Ni tuota. Mie aattelin, et nii, Lepolan [hautausmaan] kohalle mie pysähyn. Nää kelpaa. Ja ko mie kaalasin sen, miul ol syli täys kukkia ko mie läksin, kaalasin sen kainaloihi ne kukkaniput ja läksin. Ai jaa. Tos on nyt toi, tos on Kölhi sille pitää antaa, no tos on nyt se kaupunginviskaali rahatoimistosta ni sille, ja täs on nyttää Sistekin isä ja äiti, mikä nyt on Sistekki, Kaakon kumin pitäjä, sille pitää viijä. Joka kerra ko se käi ulkomailla se toi aina suklaalevyn mulle, ja siihe pitää panna kukkia ja siihe pitää. - - Einen haualle läksin, ni miun pit pitää sitä yhtä kimppua et se menee Einen haualle astikka. Se ois jääny sille käytävälle. Ko mie hiljaa kävelin ja kattelin et ai tos on ton hauta, no nii, et toho (naurua). Sinne ne kelpas, ei kukaa valittanu et älä laita miulle. (Haastattelu 1.10.2014.) 
Kauppias kertoo tarinan hiljaisesta toripäivästä, mutta korostaa samalla vakituisten asiakkaiden merkitystä ja verkostoa, jonka hän oli torille luonut. Haastattelussa kauppias viittasi useaan otteeseen siihen, että suurin osa hänen asiakkaistaan on jo läheisellä hautausmaalla. Asiakkaiden poismenoon viittaaminen kertoi paitsi torin hiljentymisestä, myös siitä, että joskus olivat olleet paremmat ajat ja vilkkaammat myynnit. Tarina kertoo kuitenkin ennen kaikkea lämpimistä asiakassuhteista, jotka kantavat vuosikymmenien yli. Tuttu kauppias vie kukkia vielä asiakkaidensa haudoillekin.

Torikauppiaat kertoivat paljon hiljaisuudesta ja kaupan hiljentymisestä (Tuuva-Hongisto 2017, 144-171.) Torin vilkkaus ja hyvät myyntiajat ovat jossakin menneessä, menneissä kultaisissa vuosissa. Menneisiin vilkkaisiin vuosiin liittyy paljon nostalgiaa ja kaipausta: silloin kaikki oli parempaa kuin nykyisin, onnellisempaa, terveempää ja jännittävämpää. (Black 2012, 171; Korkiakangas 1999, 171-173.) Toisaalta torin vilkkauden sijoittaminen menneeseen ja myynnin hiljaisuuden korostaminen liittyivät myös siihen, ettei torilla ole tapana rehennellä hyvillä myynneillä. Kaupanteon hiljaisuudesta kertominen on keskeinen puhetapa kuvata toria ja osa torikaupasta kertomisen perinnettä. Torilla usein toisteltu tokaisu tiivistää hyvin hiljaisuuden luonteen: "Aamupäivällä joku kysy kelloa, iltapäivällä on ollu hiljasempaa".

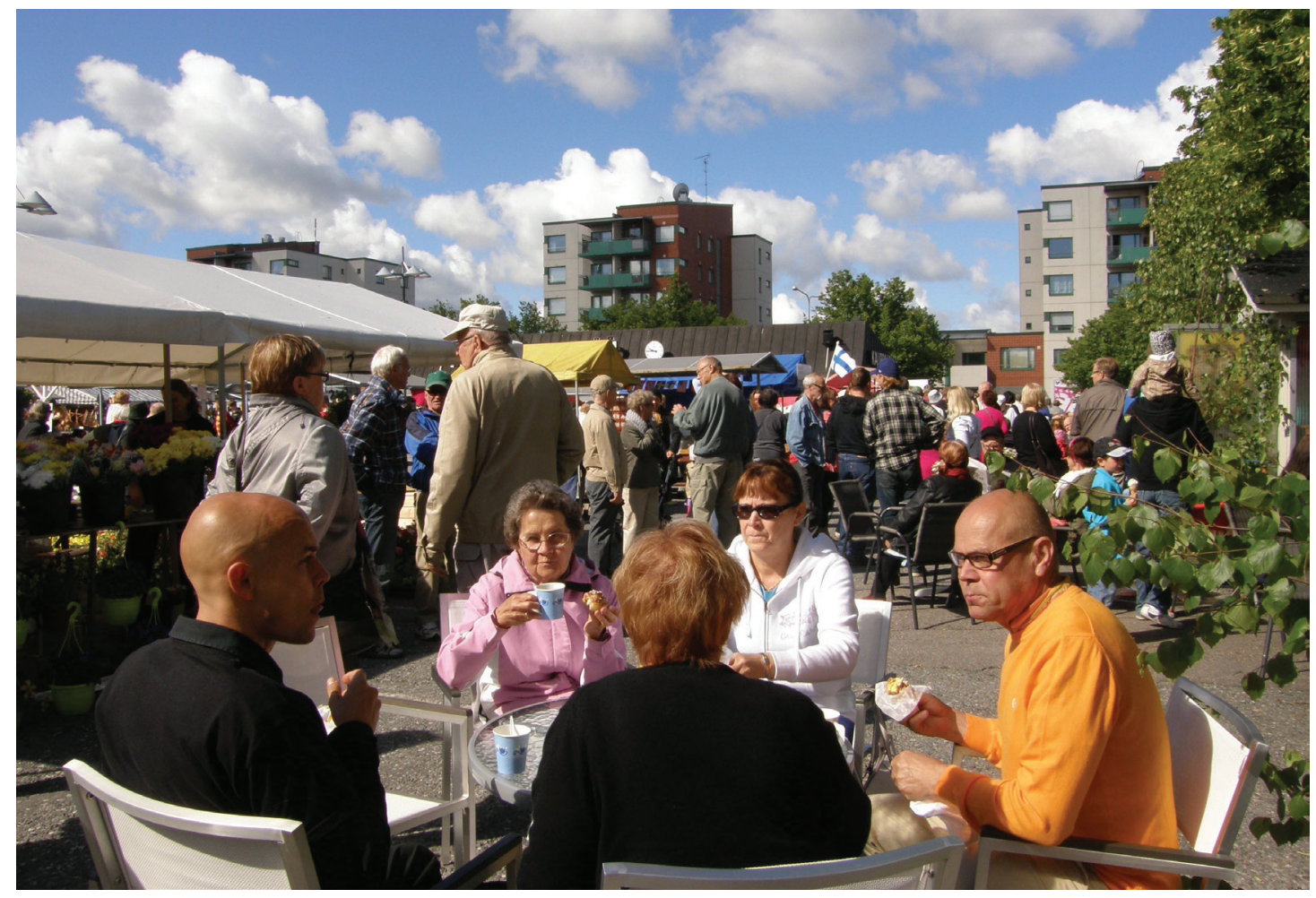

Kuva 3. Kahvikioskit myyvät vetyjä ja atomeja, kinkulla ja kananmunalla täytettyjä lihapiirakoita. Asiakkaita kahvilla ja vedyllä juhannuksena 2014. Kuva: Sari Tuuva-Hongisto. 
Sari Tuuva-Hongisto: Kaupanteon perinteitä Lappeenrannan kauppatorilla

[http://www.elore.fi/arkisto/2_17/tuuva-hongisto.pdf]

\section{LOPUKSI: "ET EI MEE KAUPAKS, TURHA LUULLAKAA HUONOO TAVARAA LÄHTEE MYYMÄÄ."}

Lappeenrannassa viljelijöiden suoramyynnin traditio on jatkunut näihin päiviin asti. Lähiseudun viljelijät ja tuottajat myyvät itse tuotteitaan. Suurin osa edelleenkin torilla käyvistä myyjistä on itse tuottajia ja viljelijöitä. Torikauppa on kuitenkin vuosien myötä muuttunut valtavirrasta vaihtoehdoksi. Arkisen, jokapäiväisen välttämättömyyden sijasta toriostoksista on tullut vaihtoehtoista ja erityistä, etuoikeutettua ja jopa lähiruokaan liittyvää luksusta (Pratt 2008). Paikallisella ruualla ja ruuantuotannolla on oma merkityksensä, joka on viime vuosien lähiruokakeskustelussa noussut yhä vahvemmin esiin. Lähiruokaringit, suoramyyntitapahtumat ja suoramyynnin kehittäminen ovat pyrkineet tuomaan ostajaa ja tuottajaa lähemmäs toisiaan. Lappeenrannassa viljelijöiden ja tuottajien myynnillä on ollut ja on yhä edelleen oma paikkansa kauppatorilla.

Tori tarjoaa paitsi lähiruokaa ja laatua, myös omalaatuisuutta, tuttuutta ja paikallista erityisyyttä. Tori on yksi harvoista paikoista, jossa urbaani kuluttaja voi kohdata ruuan tuottajan. Jo se on kokemuksena tärkeää (Black 2012, 142). Lappeenrannan torilla on runsaasti omia paikallisia erikoisuuksiaan, joista tunnetuimpia ovat "vedyt ja atomit". Myös Viipurin rinkelit, Lemin perunat sekä viljelijätorin perinne luovat oman erityisyytensä torille. Torikaupalle on myös luonteenomaista omanlaisensa tunnelma ja elämyksellisyys, jonka voi katsoa tuovan tuotteille oman lisäarvonsa. Toria määrittävät myös supliikki ja elävä puhekulttuuri, jossa vaihdetaan muutakin kuin vain pakolliset repliikit. Vuorovaikutus myyjien ja asiakkaiden kanssa muodostaa osansa torin viehätyksestä ja kokemuksellisuudesta. Torikaupassa kulttuurinen arvo syntyy paikallisuudesta ja autenttisuudesta, laadusta, kohtaamisista ja personoidusta kaupanteosta.

Torikaupalle ominaista ovat pitkät asiakassuhteet, luottamus ja laatu, kuten Jelena Ivanišević ja Melanija Belaj (2013) ovat kuvanneet tutkimuksessaan zagrebilaisesta Dolacin ruokatorista. Dolacissa ostaminen perustuu luottamukseen ja lojaalisuuteen, ostajat tuntevat myyjät henkilökohtaisesti ja ostajat ovat kenties perineet vakituisen myyjän äidiltään tai isoäidiltään. Ivanišević ja Belaj kuvaavat tätä suhdetta personoiduksi ostamiseksi ja personoiduksi tuottamiseksi. Myyjien ja ostajien välinen kanssakäynti perustuu luottamukseen, joka pohjautuu vuosikausien ja sukupolvien asiakkuuteen. Dolacissa, kuten Lappeenrannassakin, oli myyjiä, jotka olivat olleet torilla neljän sukupolven ajan, ja samoja asiakkaita oli saatettu palvella jopa viisikymmentä vuotta. Paikalliseen ruokakulttuuriin kuului, että myös ruuan tuottajat pysyivät perheiden ja sukujen traditioina. Lappeenrannassa suurin osa vakituisista myyjistä on tuottajia. Tuottajien myyntitoimintaa laajemminkin luonnehtii luottamus, kunnia, käsityöläisyys, aitous ja autenttisuus (Shepherd 2007, 126).

Tiiviit asiakassuhteet ovat torin perusta. Ne ovat myös perusta torin keskinäiselle kilpailulle ja kateudellekin. Torin "yhteinen henki" saattaa näyttäytyä hyväntuulisena ja ystävällisenä, vaikka tiivis moraaliyhteisö pitää tarkasti huolen siitä, että kauppiaiden kesken vallitsee tarkka hierarkia ja kova kilpailu. Luottamuksen tai autenttisuuden rikkominen nähtiinkin kauppiaiden keskuudessa pahimpina rikkomuksina 
sekä juoruilun aiheina. (ks. Shepherd 2007; Tuuva-Hongisto 2017,121-127.) Juoruilu on myös keino ylläpitää laatua ja luottamusta: huonosta tavarasta kulkevat huhut olivat myös asiakassuhteiden ylläpitämisen kannalta haitallisia.

Mitä sinne viet myyntiin niin se on katottava mitä viet. Et ei mee kaupaks, turha luullakaa huonoo tavaraa lähtee myymää. Ei se oo, eikä se oo rehellistäkää sanon minä. Mutta, mutta. En tiijä sit. Kuka myy mitä myy. (Haastattelu 1.10.2014.)

Kauppiaat olivat hyvin tietoisia siitä, mitä halusivat tai voivat julkisesti kertoa (ks. myös Makkonen 2010, 51). He kertoivat toria "ulospäin" ja parhain päin, johon esimerkiksi juoruilu tai keskinäiset ristiriidat eivät kuulu. Yhteisö määrittää sitä, mitä ja miten kerrotaan ja mitä muistellaan (Erll 2008; Fingerroos \& Haanpää 2006). Kauppiaita yhdisti torin hiljaisuus ja kaupanteon vähäisyys, joka oli myyjille turvallinen puheenaihe. Myyjät välttelivätkin hyvällä myynnillä rehentelyä tai kerskailua ja valittivat runsaasti kaupanteon hiljaisuutta. Se oli sekä yhteinen ja jaettu kokemus että yhteisöllisen ja yhteisen muistin ja kerronnan peruspilari. Kertomukset hiljaisuudesta olivat myös keskeinen keino karttaa kateuden kohteeksi joutumista. Hyvät myynnit ja vilkas kaupanteko sijoitettiin menneeseen. (Tuuva-Hongisto 2017, 144.)

Oma roolini sekä tutkijana että torilla kauppaa tehneenä myyjänä antoi hyvän asetelman tutkia toria sisältäpäin myyjien kuvaamana ilmiönä (ks. Morales 2009). Toisaalta sisäpiiriläisyys oli myös haitta: monet myös inmettelivät sitä, että miksi inmeessä juuri minä olin tekemässä kirjaa torista. Taustalla kuulsi toisinaan myös se, ettei minulle - yhden torikauppaperheen jäsenelle - välttämättä haluttu kertoa kaikkea. Tulkinnoissa oli varovaisuutta. Juoruilua tai toisista kauppiasta kertomista kartettiin, enkä useinkaan haastatteluissa kuullut niitä tarinoita, joita tunsin entuudestaan. Tunnetuistakin kauppiaista puhumista saatetiin vältellä. En tästä syystä tutkimuksessani tuo esiin esimerkiksi "merkittäviä" kauppiaita tai nimeä keskeisiä henkilöitä. En myöskään haastatellut tutkimustani varten omaa perhettäni, ja päädyin häivyttämään haastateltujen henkilöllisyyden haastattelusitaateista. Kateus ja juoruilu ovat torilla vahvassa roolissa, mutta tutkimushaastatteluissa kateudesta puhuminen siirrettiin yleisemmälle tasolle. Kerrottiin juoruilusta ja kateudesta, mutta vältettiin itse juoruilemasta tai kadehtimasta (ks. esim. Saarikoski 2006).

Tori syntyy kauppiaistaan. Tori on osa heitä ja he ovat osa toria. Suhde toriin on vastavuoroinen. Torikauppiaat ovat tärkeä osa torin olemusta ja torin identiteettiä. (Ks. myös Shepherd 2007, 19.) Myyjät käyvät torilla paitsi ansaitakseen elantonsa, myös siksi, että tori on heille tärkeä osa omaa identiteettiä. Monet myyjät kertoivatkin torikaupan olevan elämäntapa ja myymisen kuin huumetta. Veri vetää kaupantekoon, vaikka kauppa ei aina niin kannattaisikaan. 


\section{TUtKIMUSAINEISTOT}

Haastattelut ja tilannenauhoitukset

Ryhmähaastattelu 28.5.2014

Ryhmähaastattelu 17.6.2014 (torilla)

Haastattelu 4.8.2014 (torilla)

Haastattelu 7.8.2014 (torilla)

Haastattelu 13.8.2014 ja 28.8.2014

Haastattelu15.8.2014

Haastattelu 21.8.2014

Haastattelu 9.9.2014

Haastattelu 17.9.2014

Haastattelu 24.9.2014

Haastattelu 1.10.2014

Haastattelu 7.10.2014 ja 25.5.2015

Haastattelu 10.10.2014 (torilla)

Haastattelu 14.10.2014

Haastattelu 6.11.2014 (torilla)

Haastattelu 14.11.2014 ja 25.11.2014

Haastattelu 14.11.2014

Haastattelu 25.11.2014

Haastattelu 22.1.2015

Lappeenrannan kilta-ilta aiheena kauppatori 10.2.2014

Haastattelu 12.2.2015

Kenttäpäiväkirja 2014-2015.

\section{Kuvat}

Kuva 1: Sari Tuuva-Hongisto, 20.6.2014.

Kuva 2: Sari Tuuva-Hongisto, 20.6.2014.

Kuva 3: Sari Tuuva-Hongisto 20.6.2014.

\section{Kirjallisuus}

Bestor, Theodore C. 2004: Tsukiji. The fish market at the center of the world. Berkeley: University of California Press. 
Sari Tuuva-Hongisto: Kaupanteon perinteitä Lappeenrannan kauppatorilla

Black, Rachel, E. 2012: Contemporary ethnography: Porta Palazzo: The anthropology of an Italian market. Philadelphia: University of Pennsylvania Press.

Erll, Astrid 2008: Cultural Memory Studies: An Introduction. - Astrid Erll \& Ansgar Nünning (eds.), Cultural memory studies. An International and Interdisciplinary Handbook. Berlin: Walter de Gruyter. 1-18.

Fingerroos, Outi 2006: Uuskareliaanit nyky-Karjalassa. - Fingerroos, Outi \& Jaana Loipponen (toim.), Nykytulkintojen Karjala. Jyväskylä: Jyväskylän yliopisto. 16-32.

Fingerroos, Outi \& Riina Haanpää 2006: Muistitietotutkimuksen ydinkysymyksiä. - Fingerroos, Outi, Riina Haanpää, Anne Heimo \& Ulla-Maija Peltonen (toim.), Muistitietotutkimus - metodologisia kysymyksiä. Helsinki: SKS. 25-48.

Heinonen, Jouko 1984: Rovaniemen markkinat. Rovaniemi: Lapin maakuntamuseo.

Ivanišević, Jelena \& Belaj, Melanija 2013: Privilege of buying local food: case study of open-air food market Dolac. [online] < https://www.academia.edu/9527611/ Privilege of buying local food case study of open-air food market Dolac $>$ [16.6. 2017.]

Kokkonen, Merja 1985: Torikauppaa Lappeenrannassa 1930-1970. Lappeenranta: Etelä-Karjalan museo.

Korjonen-Kuusipuro, Kristiina \& Anna-Kaisa Kuusisto-Arponen 2017: Muistelun monen muodot - kertomus, kehollisuus ja hiljaisuus paikan tietämisen tapoina.

- Elore 24(1): 1-17 [online]. < http://www.elore.fi/arkisto/1-17/korjonenkuusipuro-kuusisto-arponen.pdf $>$ [9.11.2017 .]

Korkiakangas, Pirjo 1999: Muisti, muistelu, perinne. -Lönnqvist, Bo \& Kiuru, Elina \& Uusitalo, Eeva (toim.), Kulttuurin muuttuvat kasvot. Johdatusta etnologiatieteisiin. Helsinki: SKS.

Kortelainen, Kaisu 2008: Penttilän sahayhteisö ja työläisyys. Muistitietotutkimus. Helsinki: SKS.

Kurttila, Terhi \& Jukka Pennanen 1992: Muuttuva tori ja ihminen. Etnografinen tutkimus Oulun kauppatorista ja sen ihmisistä vuosisadan alusta nykypäivään. Oulu: Oulun yliopisto.

Lappalainen, Sirpa, 2007: Johdanto. Mikä inmeen etnografia? - Lappalainen, Sirpa \& Hynninen, Pirkko \& Kankkunen, Tarja \& Lahelma, Elina \& Tolonen, Tarja (toim.), Etnografia metodologiana. Lähtökohtana koulutuksen tutkimus. Tampere: Vastapaino. 9-14.

Lindh, Adam 1885: Lyhykäinen kertomus Lappeenrannasta. Helsinki: SKS.

Lähteenmäki, Maria \& Helena Ruotsala 2006: Matkalla pohjoiseen - lappilaisuuden ja karjalaisuuden konstruktioita. - Fingerroos, Outi \& Jaana Loipponen (toim.), Nykytulkintojen Karjala. Jyväskylä: Jyväskylän yliopisto. 229-250.

Makkonen, Elina 2009: Muistitiedon etnografiaa tuottamassa. Joensuu: Joensuu yliopisto.

Morales, Alfonso 2009: Public markets as community development tools. - Journal of Planning Education and Research 28(4): 426-440.

Nora, Pierre 1998: Era of commemoration - Realms of memory: the construction of French Past III. New York: Barnes \& Noble. 
Peltonen, Ulla-Maija 2012: Alessandro Portelli ja muistitiedon erityisyys. - Portelli, Alessandro, Käsky on täytetty. Historia, muisti ja verilöyly Roomassa 1944. Turku: Faros.

Plattner, Stuart 1982: Economic decision making in a public marketplace. American Ethnologist 9(2): 399-420.

Portelli, Alessandro 2012: Käsky on täytetty. Historia, muisti ja verilöyöy Roomassa 1944. Turku: Faros.

Pratt, Jeffrey 2008: Food values: The local and the authentic. Research in economic anthropology 28: 53-70.

Saarikoski, Helena 2006: Kateus, juoru, kiusaaminen - esseitä henkisestä yhteisöväkivallasta. Helsinki: Nemo.

Sademies, Tapio 1990: Euroopan kolme parasta toria. Optio 1.11.1990.

Shepherd, Robert J. 2007: When culture goes to market: Space, place and identity in an urban marketplace. New York: Peter Lang Publishing.

Sivula, Anna 2013: Puuvillatehtaasta muistin paikaksi. Teollisen kulttuuriperintöprosessin jäljillä. - Tuomi-Nikula, Outi, Riina Haanpää \& Aura Kivilaakso (toim.), Mitä on kulttuuriperintö? Helsinki: SKS. 161-19

Tuuva-Hongisto, Sari 2017: Torikaupan tarinat. Lappeenrannan kauppatorin muistitietohistoria. Helsinki: Partuuna.

Varsta, Martti 1946: Mikkelin kaupungin markkinat loistokautenaan 1838-1867. Taloushistoriallinen tutkielma. Mikkeli: Mikkelin kaupunki.

Ukkonen, Taina 2000: Menneisyyden tulkinta kertomalla. Muistelupuhe oman historian ja kokemuskertomusten tuottamisprosessina. Helsinki: SKS.

Filosofian tohtori Sari Tuuva-Hongisto on tutkija Historia- ja maantieteiden laitoksella Itä-Suomen yliopistossa. 